\title{
Treatment cost of narcolepsy with cataplexy in Central Europe
}

\author{
This article was published in the following Dove Press journal: \\ Therapeutics and Clinical Risk Management \\ 18 November 2016 \\ Number of times this article has been viewed
}

\author{
Petra Maresova' \\ Michal Novotny ${ }^{2,3}$ \\ Blanka Klímová ${ }^{4}$ \\ Kamil Kuča ${ }^{3,5}$ \\ 'Department of Economics, Faculty \\ of Informatics and Management, \\ ${ }^{2}$ Department of Chemistry, Faculty \\ of Science, University of Hradec \\ Králové, ${ }^{3}$ Biomedical Research \\ Center, University Hospital Hradec \\ Králové, ${ }^{4}$ Department of Applied \\ Linguistics, Faculty of Informatics and \\ Management, ${ }^{5}$ Faculty of Informatics \\ and Management, University of \\ Hradec Králové, Hradec Králové, \\ Czech Republic
}

Background: Narcolepsy is a lifelong, rare neurological sleep disorder characterized by chronic, excessive attacks of daytime sleepiness. This disease is often extremely incapacitating, interfering with every aspect of life, in work and social settings.

Objective: The purpose of this study is to specify the treatment costs of patients in Central Europe (Czech Republic), while the attention is mainly paid to the drugs that were fully or partially covered by public health insurance. Furthermore, concomitant therapy is also evaluated, since it incurs a certain financial burden for patients and their family members. On the basis of the calculated costs, impact on the public budget is evaluated.

Patients and methods: This study monitors the direct costs of the drugs for 13 patients, who represent $\sim 1.3 \%$ of the total number of diagnosed patients in the Czech Republic, and evaluates the costs associated with their treatment during the period from January 9, 2011 to April 23, 2013.

Results: Most of the treatment costs $(\sim 80 \%)$ were covered by publicly available sources. This finding is also true for the concomitant therapy of comorbidities. Additional payments for the drugs constitute about $20 \%$ of the total costs.

Keywords: cataplexy, cost, narcolepsy, orphan drug, rare disease, sodium oxybate

\section{Introduction}

Narcolepsy is one of the orphan neurological diseases. This disabling illness often starts in the second or third decade of human life. The major symptom of narcolepsy is excessive daytime sleepiness (EDS). The typical manifestation is a feeling of sleepiness fluctuating during the day and episodes of uncontrollable sleep recurring daily or almost daily. The second most common and specific symptom of narcolepsy is cataplexy. Cataplexy includes an unexpected loss of voluntary muscle tone with preserved consciousness ${ }^{1}$ and is very often triggered by emotion. The frequency of cataplexy is variable. It may occur once or less per year to several times per day. The prevalence of narcolepsy is estimated to be $\sim 25$ per 100,000 in Caucasian populations. ${ }^{2}$

This disease is often connected with pediatric age. Many studies have dealt with pathophysiology of narcolepsy and its effect on pediatric age. Rocca et $\mathrm{al}^{3}$ investigated behavioral aspects and quality of life in children and adolescents with type 1 narcolepsy (NT1). Meletti et $\mathrm{al}^{4}$ reported for the first time in humans the brain structures whose neural activity was specifically and consistently associated with emotion-induced cataplexy. To achieve this goal, drug-naïve children and adolescents with recent-onset NT1 were investigated. Han et $\mathrm{al}^{5}$ identified rare allelic variants and HLA alleles in narcolepsy patients with hypocretin (orexin, Hcrt) deficiency. Partinen et $\mathrm{al}^{6}$ dealt with epidemiological observations from studies in People's Republic of China and
Biomedical Research Centre, University Hospital Hradec Králové, Sokolska 58I, 50005 Hradec Kralove, Czech Republic Tel +420603289I66

Email kamil.kuca@fnhk.cz 
suggested a role for H1N1 virus infections as a trigger for narcolepsy. Although the pathological mechanisms are unknown, an H1N1 virus-derived antigen might be the trigger. Khatami et $\mathrm{al}^{7}$ introduced the first prospective webbased European narcolepsy database hosted by the European Narcolepsy Network.

Major progress in the treatment of narcolepsy and cataplexy has been made in the past few years. In 2006, a promising compound called sodium oxybate was introduced. It was found to be effective in controlling all main symptoms of narcolepsy with cataplexy: daytime sleepiness, cataplexy, and disturbed nighttime sleep. ${ }^{8}$ The efficacy of sodium oxybate on the cataplectic symptoms of narcolepsy has been confirmed in a few randomized, multicenter, double-blind, placebo-controlled studies. ${ }^{9-11}$ Chemically, sodium oxybate is the sodium salt of gamma-hydroxybutyrate and is supplied as an oral solution. The US Food and Drug Administration (FDA) licensed sodium oxybate for the treatment of EDS and cataplexy in patients with narcolepsy. In the European Union (EU), it is licensed for the treatment of narcolepsy with cataplexy. The European Federation of Neurescience Societies (2006) ${ }^{12}$ recommended the use of sodium oxybate as a first-line therapy for cataplexy.

Nevertheless, sodium oxybate is an expensive therapy. The drug costs, whether borne by patients or by managed care, can present a barrier to treatment. The issue of relationship costs of health care vs their further development - is the key in many diseases whose treatment is either highly costly or an increase in the incidence of diseases is expected. ${ }^{13-15}$

The purpose of this study is to specify the treatment costs of patients with narcolepsy with cataplexy in Central Europe (Czech Republic). Attention is mainly paid to the drugs that are fully or partially covered by public health insurance and to the complementary drugs which incur a certain financial burden for patients and their family members. On the basis of the calculated costs, impact on the public budget is evaluated.

\section{Patients and methods}

This study used Drummond's methodology. ${ }^{16}$ According to this methodology, the costs are divided into two categories. The first category includes the costs of creation and running of health care programs, and the costs are perceived as the used sources. This category involves both variable and fixed costs and is therefore often called direct costs. The second category includes the costs which are imposed on patients and their families. Apart from the direct costs, this category also includes the costs in the form of a loss of working hours when taking a treatment. These production losses contribute to the indirect costs of services or programs. The so-called mental costs, subsequently causing mental harm, are similar in both categories. They play a significant role in patient's and his/her family's decision-making process. These indirect costs, however, are not researched in this study.

This study aims at the costs of the drugs that are used mainly in the treatment of this disease and at the concomitant therapy which is usually covered only partly by the public health insurance in the Czech Republic. This partially specifies the burden on the patients themselves or their family members. The study monitors 13 patients, who represent $\sim 1.3 \%$ of the total number of diagnosed patients in the Czech Republic, and evaluates the costs of their treatment during the period from January 9, 2011 to April 23, 2013. In the Czech Republic, there are two centers for the treatment of patients suffering from narcolepsy with cataplexy. The treatment with sodium oxybate is exclusively done in one of the centers - the Charles University 1st Medical Faculty and General Teaching Hospital in Prague.

The authors institution (the University of Hradec Kralove) does not require ethical approval or patient consent for this study because the data used are freely available on request.

\section{Results}

This study, specifying the reimbursable and unpaid drugs from the public health insurance, includes 13 patients. Special attention is paid to sodium oxybate. The data were collected from the Public Health Insurance Company in the Czech Republic.

\section{Costs of sodium oxybate $\left(\right.$ Xyrem $\left.^{\circledR}\right)$}

According to the valid summary of product characteristics, the recommended initial dose is $4.5 \mathrm{~g}$ of sodium oxybate per day. It is divided into two equal doses of $2.25 \mathrm{~g}$. The dose should be titrated to an effective dose according to the efficiency and tolerance up to the maximum possible dose of $9 \mathrm{~g}$ per day, divided into two equal doses of $4.5 \mathrm{~g}$. The recommended daily dose according to the World Health Organization is $7.5 \mathrm{~g}$ per day. In the real clinical practice, an average dose was $7.4 \mathrm{~g}$ per day. The common daily therapeutic dose was set by State Institute for Drug Control in the Czech Republic (SUKL) at $9 \mathrm{~g}$ per day. At a dose of $7.4 \mathrm{~g}$ per day, one package of this medicine lasts for 12 days, and thus, the costs of the daily treatment are 30 EUR and the annual costs are 10,790 EUR. The reimbursement of sodium oxybate $\left(\right.$ Xyrem $\left.^{\circledR}\right)$ is 354.7 EUR per $180 \mathrm{~mL}(500 \mathrm{mg} / \mathrm{mL})$. One package contains $90 \mathrm{~g}$ of this efficient drug. The costs of this medicine for the period of one year in the Czech Republic are illustrated in Table 1. 
Table I Costs of sodium oxybate in the Czech Republic

\begin{tabular}{lll}
\hline Daily dose & $\begin{array}{l}\text { Costs per } \\
\text { day, EUR }\end{array}$ & $\begin{array}{l}\text { Costs per } \\
\text { I2 months, EUR }\end{array}$ \\
\hline 4.5 g per day & 20 & 7,630 \\
7.4 g per day & 30 & 10,790 \\
9 g per day & 41 & 14,860 \\
\hline
\end{tabular}

Note: Authors' own calculations based on the cited data. ${ }^{18}$

Further analyses are based on the doses used in the real clinical practice, ie, $7.4 \mathrm{~g}$ per day. Another entry parameter for the pharmaco-economic analysis is a recommended price for the end consumer for $180 \mathrm{~mL}(500 \mathrm{mg} / \mathrm{mL})=354.7 \mathrm{EUR}$ (SUKL). Table 2 specifies the population of patients in the Czech Republic, costs per analyzed period, the year when they were registered at the Public Insurance Company, and the costs of medicine per year.

The costs of the total number of patients in one year covered by the public health insurance are $10,789.9 \times 13=140,269$ EUR per year.

\section{Costs of the concomitant therapy}

Table 3 provides an overview of other drugs which the patients were taking together with sodium oxybate. The drugs included in this category are the drugs that are directly connected with narcolepsy with cataplexy or with the direct psychiatric comorbidities and other efficient drugs.

The specification of the costs for the specific patients with respect to the drugs taken by the patients is provided in Table 4. Attention is paid to the proportion of the costs incurred by the patients and to the amount paid by the public resources.
The range of costs for individual patients differs significantly; three patients did not have any concomitant therapy in the monitored period. The highest total costs were 1,048.6 EUR with one patient covered from his own resources. Generally, most of the costs for the treatment of these patients $(\sim 84 \%)$ are covered by publicly available sources. Similar situation is observed in the case of comorbidities. There are additional payments for the patients, which constitute about $20 \%$. Nevertheless, patient B paid for most of his treatment by himself. However, this is an exception.

A more detailed analysis of the costs connected with the drugs of the monitored disease shows (Table 5) that most of the costs are covered by public health insurance, and patients are not so much burdened with the costs. From the $20 \%$ burden of costs mentioned earlier, the main part is the reimbursement of comorbidities.

\section{Discussion}

The situation in the Czech Republic with respect to the availability and reimbursement of drugs is relatively promising. This study shows that the public health insurance covers most of the costs of drugs used for the treatment of narcolepsy with cataplexy. Figure 1 describes the price of the drug in relation to parameters: sodium oxybate $500 \mathrm{mg} / \mathrm{mL}$, usual daily therapeutic dose 7,500 number of package 12 . Figure 1 compares the available data on the prices in the European countries. It is obvious that the highest price is reported in Italy, which is comparable with that in Slovenia, Austria, and Germany. On the contrary, the lowest price is reported in Cyprus and Denmark. Thus, this international comparison shows a relatively favorable price for this drug.

Table 2 Consumption of sodium oxybate by the monitored patients

\begin{tabular}{|c|c|c|c|c|c|}
\hline Patient & Sex & $\begin{array}{l}\text { Year of } \\
\text { birth }\end{array}$ & $\begin{array}{l}\text { Consumption of sodium oxybate for } \\
\text { the monitored period (in the number } \\
\text { of packages of Xyrem } 500 \mathrm{mg} / \mathrm{mL} \text { ) }\end{array}$ & $\begin{array}{l}\text { Costs per } \\
\text { year (EUR) }\end{array}$ & $\begin{array}{l}\text { Costs per analyzed } \\
\text { period (EUR) }\end{array}$ \\
\hline $\bar{A}$ & Male & 1942 & $\begin{array}{l}\text { - For the consumption of } 7.4 \mathrm{~g} \text {, it is a } \\
\text { purchase of } 69.5 \text { packages }\end{array}$ & - $10,789.9$ & - $24,345.4$ \\
\hline B & Male & 1945 & - For $4.5 \mathrm{~g}$, it is 42.26 packages & - $7,429.8$ & - $16,976.5$ \\
\hline C & Male & 1948 & $\begin{array}{l}\text { - For the maximum dose of } 9 \mathrm{~g} \text {, it is } \\
84.52 \text { packages }\end{array}$ & - $14,859.6$ & - $33,953.1$ \\
\hline $\mathrm{D}$ & Male & 1951 & & & \\
\hline$E$ & Male & 1965 & & & \\
\hline $\mathrm{F}$ & Male & 1969 & & & \\
\hline G & Male & 1970 & & & \\
\hline $\mathrm{H}$ & Male & 1970 & & & \\
\hline 1 & Female & 1972 & & & \\
\hline J & Female & 1976 & & & \\
\hline $\mathrm{K}$ & Male & 1981 & & & \\
\hline$L$ & Male & 1983 & & & \\
\hline M & Male & 1994 & & & \\
\hline
\end{tabular}

Note: Authors' own calculation based on the data from the Public Health Insurance Company in the Czech Republic. 
Table 3 Overview of anatomical therapeutic chemical groups (ATC) of the monitored patients

\begin{tabular}{|c|c|c|}
\hline Patient & Number of other types of drugs & ATC \\
\hline \multirow[t]{22}{*}{$A$} & 19 (other efficient drugs) & N06DA02 - Donepezil \\
\hline & & N06DX02 - Ginkgo folium \\
\hline & & N06BX03 - Piracetam \\
\hline & & A07EA06 - Budesonide \\
\hline & & C05CA53 - Diosmin, combinations \\
\hline & & A02BC03 - Lansoprazole \\
\hline & & A09AA02 - Multienzymes (lipase or protease) \\
\hline & & A02BC02 - Pantoprazole \\
\hline & & AI2BAOI - Potassium chloride \\
\hline & & H02AB04 - Methylprednisolone \\
\hline & & J0IMA02 - Ciprofloxacin \\
\hline & & C03CAOI - Furosemide \\
\hline & & A07EC02 - Mesalazine \\
\hline & & MOIAXI7 - Nimesulide \\
\hline & & C05CA5I - Rutoside, combinations \\
\hline & & M0IAB05 - Diclofenac \\
\hline & & C04AD03 - Pentoxifylline \\
\hline & & CI0AA05 - Atorvastatin \\
\hline & & AI2AX - Calcium, combinations with vitamin $D$ and/or other drugs \\
\hline & 3 (directly related drugs) & N06BA07 - Modafinil \\
\hline & & N06AB06 - Sertraline \\
\hline & & N06ABIO - Escitalopram \\
\hline \multirow[t]{8}{*}{ B } & 7 (other efficient drugs) & G04BD06 - Propiverine \\
\hline & & C05CA04 - Troxerutin \\
\hline & & V08AB07 - loversol \\
\hline & & SOIFBOI - Phenylephrine \\
\hline & & CI0AA05 - Atorvastatin \\
\hline & & M02AAI 5 - Diclofenac \\
\hline & & CI0AA07 - Rosuvastatin \\
\hline & I (directly related drugs) & N06ABI0 - Escitalopram \\
\hline C & 0 & \\
\hline \multirow[t]{18}{*}{ D } & I3 (other efficient drugs) & C09AA05 - Ramipril \\
\hline & & C07AB02 - Metoprolol \\
\hline & & C03AA03 - Hydrochlorothiazide \\
\hline & & D06AX - Other antibiotics for topical use \\
\hline & & V08AB07 - loversol \\
\hline & & C03DA0I - Spironolactone \\
\hline & & R03BB0I - Ipratropium bromide \\
\hline & & AlOBA02 - Metformin \\
\hline & & AIOAD0I - Insulin (human) \\
\hline & & CI0AA05 - Atorvastatin \\
\hline & & A02BC02 - Pantoprazole \\
\hline & & B0IAC06 - Acetylsalicylic acid \\
\hline & & B0IAC04 - Clopidogrel \\
\hline & 5 (directly related drugs) & N06BA04 - Methylphenidate \\
\hline & & N06BA07 - Modafinil \\
\hline & & N03AEOI - Clonazepam \\
\hline & & N06AA04 - Clomipramine \\
\hline & & N06AXI4 - Tianeptine \\
\hline $\mathrm{E}$ & 0 & \\
\hline \multirow[t]{4}{*}{$\mathrm{F}$} & 2 (other efficient drugs) & J0IFA09 - Clarithromycin \\
\hline & & N02AX02 - Tramadol \\
\hline & 2 (directly related drugs) & N06BA04 - Methylphenidate \\
\hline & & N06AB03 - Fluoxetine \\
\hline \multirow[t]{3}{*}{ G } & I (other efficient drugs) & C07AB02 - Metoprolol \\
\hline & 2 (directly related drugs) & N06AXI4 - Tianeptine \\
\hline & & N06AA04 - Clomipramine \\
\hline
\end{tabular}


Table 3 (Continued)

\begin{tabular}{|c|c|c|}
\hline Patient & Number of other types of drugs & ATC \\
\hline \multirow[t]{3}{*}{$\mathrm{H}$} & I (other efficient drugs) & DOIACOI - Clotrimazole \\
\hline & 2 (directly related drugs) & N06BA07 - Modafinil \\
\hline & & N06ABI0 - Escitalopram \\
\hline \multirow[t]{11}{*}{ I } & 8 (other efficient drugs) & J0ICR02 - Amoxicillin and enzyme inhibitor \\
\hline & & R03AC02 - Salbutamol \\
\hline & & D07XC0I - Betamethasone \\
\hline & & MOIAXI7 - Nimesulide \\
\hline & & R06AX27 - Desloratadine \\
\hline & & V04CL - Tests for allergic diseases \\
\hline & & M02AAI 0 - Ketoprofen \\
\hline & & R0IAD05 - Budesonide \\
\hline & 3 (directly related drugs) & N06AA04 - Clomipramine \\
\hline & & N05BA I 2 - Alprazolam \\
\hline & & N06BA07 - Modafinil \\
\hline \multirow[t]{11}{*}{ J } & I0 (other efficient drugs) & G0IAF02 - Clotrimazole \\
\hline & & R05DA04 - Codeine \\
\hline & & R03ALOI - Fenoterol and ipratropium bromide \\
\hline & & D07BB03 - Triamcinolone and antiseptics \\
\hline & & R06AX27 - Desloratadine \\
\hline & & JOIEEOI - Sulfamethoxazole and trimethoprim \\
\hline & & J0ICR02 - Amoxicillin and enzyme inhibitor \\
\hline & & R03AK08 - Formoterol and beclometasone \\
\hline & & DIIAHOI - Tacrolimus \\
\hline & & D07AC0I - Betamethasone \\
\hline & I (directly related drugs) & N06BA04 - Methylphenidate \\
\hline $\mathrm{K}$ & I (other efficient drugs) & N06BA07 - Modafinil \\
\hline \multirow[t]{2}{*}{ L } & I (other efficient drugs) & MOIAX25 - Chondroitin sulfate \\
\hline & I (directly related drugs) & N06BA07 - Modafinil \\
\hline \multirow[t]{3}{*}{$M$} & I (other efficient drugs) & A03FA07 - Itopride \\
\hline & 2 (directly related drugs) & N06BA07 - Modafinil \\
\hline & & N06AA04 - Clomipramine \\
\hline
\end{tabular}

Note: Authors' own processing based on the data from the Public Health Insurance Company in the Czech Republic.

Table 4 Concomitant therapy and its prices of all other taken drugs for a specific patient for 12 months (EUR)

\begin{tabular}{|c|c|c|c|c|c|c|}
\hline \multirow[t]{2}{*}{ Patient } & \multicolumn{2}{|c|}{$\begin{array}{l}\text { Indicative price of all other } \\
\text { taken drugs per patient for } \\
\text { I } 2 \text { months }\end{array}$} & \multicolumn{2}{|c|}{$\begin{array}{l}\text { Indicative additional } \\
\text { payment (paid by the } \\
\text { patient) }\end{array}$} & \multicolumn{2}{|c|}{$\begin{array}{l}\text { Maximum } \\
\text { reimbursement from the } \\
\text { health insurance }\end{array}$} \\
\hline & EUR & $\%$ & EUR & $\%$ & EUR & $\%$ \\
\hline$A$ & $5,231.2$ & 100 & $1,048.6$ & 20 & $4,217.3$ & 80 \\
\hline B & 235.5 & & 172.0 & 73 & 63.5 & 27 \\
\hline C & 0 & & 0 & 0 & 0 & 0 \\
\hline $\mathrm{D}$ & $2,3 \mid 1.4$ & & 591.8 & 26 & $1,719.6$ & 74 \\
\hline$E$ & 0 & & 0 & 0 & 0 & 0 \\
\hline $\mathrm{F}$ & 351.3 & & 88.4 & 25 & 262.9 & 75 \\
\hline $\mathrm{G}$ & 18.8 & & 7.4 & 39 & 11.4 & 61 \\
\hline $\mathrm{H}$ & $1,954.7$ & & 189.7 & 10 & $1,765.0$ & 90 \\
\hline I & $\mathrm{I}, 443 . \mathrm{I}$ & & 27.4 & 2 & $\mathrm{I}, 4 \mid 5.7$ & 98 \\
\hline J & 195.9 & & 46.6 & 24 & 149.3 & 76 \\
\hline K & 273.1 & & 0 & 0 & 273.1 & 100 \\
\hline L & 968.3 & & 7.2 & I & 961.2 & 99 \\
\hline$M$ & 878.0 & & 21.0 & 2 & 856.9 & 98 \\
\hline Total & $2,718,397$ & & 30 & 16 & $2,402,67$ & 84 \\
\hline
\end{tabular}

Note: Authors' own processing based on the cited data. ${ }^{18}$ 
Table 5 Price of the additional payment and reimbursement from the public health insurance in relation to the drug and its link to the monitored disease (EUR)

\begin{tabular}{|c|c|c|c|}
\hline $\begin{array}{l}\text { Patient and the type } \\
\text { of the drug }\end{array}$ & $\begin{array}{l}\text { Indicative price } \\
\text { for } 12 \text { months }\end{array}$ & $\begin{array}{l}\text { Indicative additional } \\
\text { payment }\end{array}$ & $\begin{array}{l}\text { Maximum reimbursement } \\
\text { from the health insurance }\end{array}$ \\
\hline A. Other efficient drugs & $2,328.6$ & $\mathrm{I}, 038.2$ & I,325.I \\
\hline Directly related drugs & $2,902.6$ & 10.4 & $2,892.2$ \\
\hline B. Other efficient drugs & 157.7 & 112.2 & 45.5 \\
\hline Directly related drugs & 77.7 & 59.8 & 18.0 \\
\hline C. Other efficient drugs & 0.0 & 0.0 & 0.0 \\
\hline Directly related drugs & 0.0 & 0.0 & 0.0 \\
\hline D. Other efficient drugs & $\mathrm{I}, 189.3$ & 561.2 & 628.1 \\
\hline Directly related drugs & $1,122.1$ & 30.6 & $1,091.5$ \\
\hline E. Other efficient drugs & 0.0 & 0.0 & 0.0 \\
\hline Directly related drugs & 0.0 & 0.0 & 0.0 \\
\hline F. Other efficient drugs & 61.4 & 14.4 & 47.0 \\
\hline Directly related drugs & 289.9 & 74.0 & 215.9 \\
\hline G. Other efficient drugs & 1.7 & 1.3 & 0.4 \\
\hline Directly related drugs & 17.0 & 6.1 & 11.0 \\
\hline H. Other efficient drugs & 5.7 & 3.7 & 2.0 \\
\hline Directly related drugs & $1,948.9$ & 185.9 & $1,763.0$ \\
\hline I. Other efficient drugs & 23.5 & 12.8 & 10.7 \\
\hline Directly related drugs & $1,419.6$ & 14.6 & $1,404.9$ \\
\hline J. Other efficient drugs & 60.5 & 16.9 & 43.6 \\
\hline Directly related drugs & 135.4 & 29.7 & 105.7 \\
\hline K. Other efficient drugs & 0.0 & 0.0 & 0.0 \\
\hline Directly related drugs & 273.1 & 0.0 & 273.1 \\
\hline L. Other efficient drugs & 12.3 & 7.2 & 5.2 \\
\hline Directly related drugs & 956.0 & 0.0 & 956.0 \\
\hline M. Other efficient drugs & 20.2 & 18.0 & 2.2 \\
\hline Directly related drugs & 857.8 & 3.0 & 854.8 \\
\hline
\end{tabular}

Note: Authors' own processing based on the cited data. ${ }^{18}$

With respect to the reimbursement of other drugs for this disease, the situation in the Czech Republic is promising; additional payments are low. The cost analysis showed that patients annually paid $20 \%$ of the costs on the drugs which they used, but in most cases it was for the treatment of comorbidities.
The Czech Republic has one of the highest availability of orphan drugs (ODs), with $74 \%$ of ODs included in the European Medicines Agency available in market. According to the study of SZP (Association of Health Insurance Companies) and VZP (Public Insurance Company), the costs of ODs have been rising in the past few years. It was

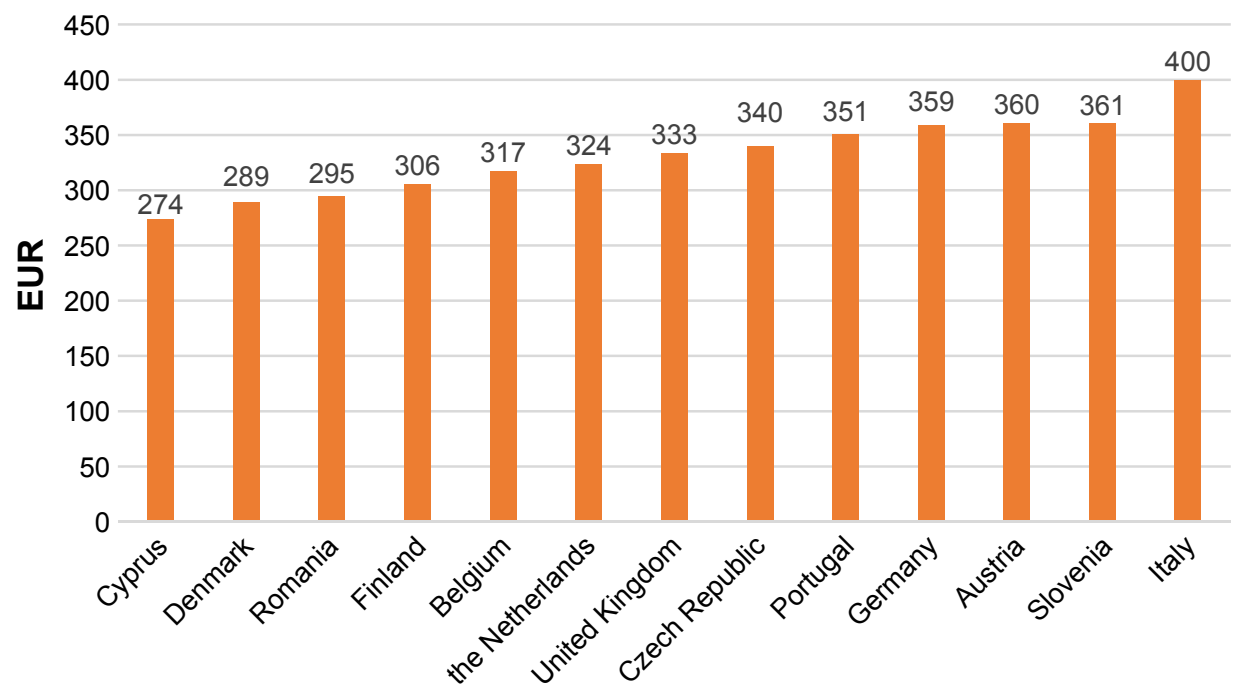

Figure I Price producer per package (EUR) - sodium oxybate.

Note: Authors' own calculation according to the drug database in individual countries. 
only in 2012 when they started to decline. If the percentage of costs is compared according to the SUKL methodology, then in 2007 the costs were at 1.8\%; however, in 2011 they rose to $4.5 \%$ in VZP and to 3\% in SZP. The year 2012 showed a slight decline to $4.49 \%{ }^{17}$

In comparison with the EU, the costs in the Czech Republic are slightly lower (gross national product in the Czech Republic is, however, significantly lower than the average gross national product in the EU). The costs in the EU in 2010 constituted $3.3 \%$ and their estimation for 2016 is $4.6 \%$. It is hoped that there would not be any increase in the costs until 2020 and that they would slightly decline. The costs in Sweden are at $\sim 3 \%$; more specifically, it is $2.7 \%$ in Sweden and 3.2\% in France. ${ }^{1}$ In comparison with the EU and Czech Republic study, their forecast a stable increase in the budget. In the Czech Republic, there has been a fear of a rapid increase in the costs of these drugs. However, with respect to the estimates for the EU countries and Czech Republic, one can expect a stop spending level. On the contrary, in the countries where these costs are lower than in the parts of the Eurozone (Sweden and France, 3.2\%), one can expect an increase in the costs.

These findings show that in the Czech Republic, there is no need to be worried about a rapid increase in the costs because a limited number of the existing drugs in combination with a small number of patients will not threaten the health system with a sharp rise in the treatment costs of ODs.

\section{Acknowledgment}

The study is supported by the Project Excellence at the Faculty of Informatics and Management of the University of Hradec Kralove, Czech Republic, and internal research Economic and Managerial Aspects in Biomedicine.

\section{Disclosure}

The authors report no conflicts of interest in this work.

\section{References}

1. Tucci V, Plazzi G. Cataplexy: an affair of pleasure or an unpleasant affair? Neurosci Lett. 2009;450(2):90-91.

2. Billiard M, Bassetti C, Dauvilliers Y, et al; EFNS Task Force. EFNS guidelines on management of narcolepsy. Eur J Neurol. 2006;13(10): $1035-1048$

3. Rocca FL, Finotti E, Pizza F, et al. Psychosocial profile and quality of life in children with Type $1>$ narcolepsy: a case-control study. Sleep. 2016;39(7):1389-1398.

4. Meletti S, Vaudano AE, Pizza F, et al. The brain correlates of laugh and cataplexy in childhood narcolepsy. $J$ Neurosci. 2015;35(33): 11583-11594.

5. Han F, Lin L, Schormair B, et al. HLA DQB $1 * 06: 02$ negative narcolepsy with hypocretin/orexin deficiency. Sleep. 2014;37(10):1601-1608.

6. Partinen M, Kornum BR, Plazzi G, Jennum P, Julkunen I, Vaarala O. Narcolepsy as an autoimmune disease: the role of H1N1 infection and vaccination. Lancet Neurol. 2014;13(6):600-613.

7. Khatami R, Luca G, Baumann CR, et al; European Narcolepsy Network The European Narcolepsy Network (EU-NN) database. J Sleep Res. 2016;25(3):356-364.

8. Dauvilliers Y, Arnulf I, Mignot E. Narcolepsy with cataplexy. Lancet. 2007;369(9560):499-511.

9. U.S. Xyrem Multicenter Study Group. A randomized, double-blind, placebo-controlled, multicenter trial comparing the effects of three doses of orally administered sodium oxybate with placebo in the treatment of narcolepsy. Sleep. 2002;25(1):42-49.

10. U.S. Xyrem Multicenter Study Group. Sodium oxybate demonstrates long-term efficacy for the treatment of cataplexy in patients with narcolepsy. Sleep Med. 2004;5(2):119-123.

11. Xyrem International Study Group. Further evidence supporting the use of sodium oxybate for the treatment of cataplexy: a double-blind, placebocontrolled study in 228 patients. Sleep Med. 2005;6(5):415-421.

12. Federation of Neurescience Societies. 2016. Available from: http:// www.fens.org/. Accessed September 24, 2016.

13. Mohelska H, Maresova P, Valis M, Kuca K. Alzheimer's disease and its treatment costs: case study in the Czech Republic. Neuropsychiatr Dis Treat. 2015;11:2349-2354.

14. Marešová $\mathrm{P}$, Mohelská $\mathrm{H}$, Dolejš J, Kuča K. Socio-economic aspects of Alzheimer's disease. Curr Alzheimer Res. 2015;12(9):903-911.

15. Marešová $\mathrm{P}, \mathrm{Klímová} \mathrm{B}, \mathrm{Kuča} \mathrm{K}$. Alzheimer's disease: cost cuts call for novel drugs development and national strategy. Ceska Slov Farm. 2015;64(1-2):25-30.

16. Drummond MF, Sculpher MJ, Torrance GW, O'Brien BJ, Stoddart GL. Methods for the Economic Evaluation of Health Care Programs. 2nd ed. New York, NY: Oxford University Press; 1997.

17. Lhotáková M, Kubáčková K. European initiative in the field of rare diseases. Current Europe. 2013;12:19-37.

18. SUKL. Drug pricing. 2015. Available from: http://www.sukl.cz/. Accessed October 15, 2015.
Therapeutics and Clinical Risk Management

\section{Publish your work in this journal}

Therapeutics and Clinical Risk Management is an international, peerreviewed journal of clinical therapeutics and risk management, focusing on concise rapid reporting of clinical studies in all therapeutic areas, outcomes, safety, and programs for the effective, safe, and sustained use of medicines. This journal is indexed on PubMed Central, CAS,

\section{Dovepress}

EMBase, Scopus and the Elsevier Bibliographic databases. The manuscript management system is completely online and includes a very quick and fair peer-review system, which is all easy to use. Visit http://www.dovepress.com/testimonials.php to read real quotes from published authors. 